\title{
The Relationship Between Traffic Sign Comprehension and Risky Traffic Behaviors
}

\author{
Burcu Tekeş ${ }^{1}$, Gaye Solmazer ${ }^{2}$, Havva Nur Alkan ${ }^{3}$
}

Tekeş, B., Solmazer, G. ve Alkan, H. N. (2021). The relationship between traffic sign comprehension and risky traffic behaviors. Nesne, 9(22), 755-769. DOI: 10.7816/nesne-09-22-01

\begin{abstract}
Keywords
Driver behavior, pedestrian

behavior, risky

behavior, traffic

sign, traffic sign

comprehension
\end{abstract}

\begin{abstract}
The current study investigates the relationship between risky traffic behaviors and traffic sign comprehension (TSC). It is hypothesized that, as traffic sign comprehension increases, unsafe traffic behaviors decrease. The data were collected online through Qualtrics from 275 participants, 177 of whom were drivers. The questionnaire package included 25 open-ended traffic sign questions, Pedestrian Behavior Scale, Mini-Driver Behavior Questionnaire with 3 additional aggressive violation items, and a demographic information form. The results indicated that TSC was significantly related to reported driver errors and lapses after controlling for age and gender. In addition, pedestrian-related TSC was significantly related to reported pedestrian transgressions, lapses, aggressive behaviors, and positive behaviors after controlling for age, gender, driver's license, and driving experience. Generally, the results were consistent with the expectations: the better that road users (drivers and pedestrians) understand traffic signs, the fewer drivers and pedestrians reported unsafe behaviors (errors and lapses for drivers; transgressions, aggressive behaviors, and lapses for pedestrians), and the more pedestrians reported positive behaviors. This finding can be explained by the fact that as the need of people to understand traffic signs increases, they avoid behaviors that will lead to accidents in traffic. For this reason, it can be predicted that comprehensively introducing children to traffic signs from an early age will contribute positively to road safety.
\end{abstract}

\section{Trafik İşaretlerini Anlayabilmenin Riskli Sürücü ve Yaya Davranışları ile İlişkisinin İncelenmesi} Öz

Bu çalışma, trafik işaretlerini anlama ile riskli sürücü ve yaya davranışları arasındaki ilişkileri araştırmaktadır. Bu çalışmada kişilerin trafik işaretlerini daha çok anlayabildikçe güvenli olmayan trafik davranışlarının (hem sürücü hem de yayalar için) azaldığı hipotez edilmektedir. Araştırmada ele alınan veriler, Qualtrics aracılığıyla 177 'si sürücü olan 275 katılımcıdan çevrimiçi olarak toplanmıştır. Veriler, 25 açık trafik işareti sorusu, Yaya Davranışı Ölçeği, Mini Sürücü Davranışı Anketi, (Saldırgan ihlaller alt ölçeği ile birlikte) ve demografik bilgi formu aracılığı ile toplanmıştır. Sonuçlar, trafik işaretlerini anlamanın yaş ve cinsiyet kontrol edildikten sonra bildirilen sürücü hataları ve ihmallerle önemli ölçüde ilişkili olduğunu göstermiştir. Ek olarak yaya davranışları incelendiğinde, trafik işaretlerini anlama, yaş, cinsiyet, ehliyet ve sürüş deneyimi kontrol edildikten sonra bile, yaya ihlalleri, hatalar, saldırgan davranışlar ve olumlu davranışlarla önemli ölçüde ilişkili bulunmuştur. Genel olarak sonuçlar beklentiler ile tutarlıdır: yol kullanıcıları (sürücüler ve yayalar) trafik işaretlerini ne kadar iyi anlarsa, o kadar az güvenli olmayan davranışlar (Sürücüler için, hata ve ihmaller; yayalar için kural ihlali, saldırgan davranışlar ve ihmaller) bildirmişlerdir. Bu bulgu, kişilerin trafik işaretlerini anlamak için duydukları gereksinim arttıkça onların trafikte kazaya yol açacak davranışlardan kaçınmaları ile açıklanabilir. Bu sebeple çocuklara küçük yaştan itibaren trafik işaretlerini iyi düzeyde tanıtmanın yol güvenliğine olumlu katkı sağlayacağı öngörülebilmektedir. 
Traffic accidents, which annually cause the deaths of 1.35 million people globally (World Health Organization, 2018), can be related to three kinds of factors (road, vehicle, and human factors) (Özkan \& Lajunen, 2011), of which the most powerful is human-related factors (Lewin, 1982). In Turkey, specifically, faults and defects accounted for 983,808 traffic accidents, associated with the deaths of 4,866 individuals. Of these faults and defects, $96.7 \%$ related to human factors, including drivers, pedestrians, and passengers (Turkish Statistical Institute [TurkStat], 2020). Therefore, the first step to reduce traffic fatalities is understanding the predictors of human factors. In addition, a literature review suggests that there is insufficient understanding of traffic signs in many countries (Dewar, 1988; Kirmizioglu \& Tuydes-Yaman, 2012; Zhang \& Chan, 2013). Hence, this study examined road users' risky behaviors as a human factor in traffic fatalities in relation to traffic sign comprehension (TSC). This study focuses on risky traffic behaviors by both drivers and pedestrians.

Driver faults cause $88.3 \%$ of traffic accidents in Turkey (TurkStat, 2020). In the literature, driver behaviors are generally conceptualized under three categories: errors, lapses, and violations (Martinussen et al., 2013; Reason et al., 1990). Specifically, errors and lapses are unintentional while violations include intentionality. Errors refer to actions that unintentionally fail to achieve the desired end, such as not checking the rear-view mirror before departing (Reason et al., 1990). Lapses are unintentional memory failures, such as forgetting where the car is parked (Özkan \& Lajunen, 2005). Violations refers to intentionally move away from the behaviors needed to operate safely in traffic (Reason et al., 1990). Violations have also been divided into two ordinary violations and aggressive violations (Lawton et al., 1997). Ordinary violations are deliberate actions that violate traffic rules, such as speeding, whereas aggressive violations have an interpersonal aggressive component directed towards other road users (Lajunen et al., 2004; Lawton et al., 1997).

Despite this difference in intentionality, these behaviors can all be classified as "aberrant driver behaviors" (Reason et al., 1990) because they prevent traffic systems from operating safely. Many studies show that accident involvement and driver behaviors are closely related to each other (Mohamed \& Lotfi, 2016; Özkan et al., 2006). More specifically, self-reported accident involvement is positively related to all driver behaviors (lapses, errors, and violations) but logistic regression shows that accidents are only predicted by errors and violations (Mohamed \& Lotfi, 2016).

Pedestrian faults (7\%) were found to be the second leading cause of traffic accidents in Turkey, after driver faults (TurkStat, 2020). Similarly, Mako and Szakonyi (2016) reported that $44 \%$ of all accidents involving pedestrians at designated pedestrian crossings occur because they display unsafe behaviors. Hence, pedestrians display unsafe behaviors, which in turn may increase their accident involvement (Mako \& Szakonyi, 2016; Zhuang \& Wu, 2011).

Like driver behaviors, pedestrian behaviors are generally conceptualized under four human factor categories (i.e. transgressions, aggressive behaviors, lapses, and positive behaviors) (Granié et al., 2013). Transgression involves deliberate non-compliance with "legal rules (crossing light, pedestrian crossing) and rules of caution (avoiding views obstructed by stopped or parked vehicles, for example)" (Granié et al., 2013, p. 836). Lapses are unintentional risky pedestrian behaviors that occur due to forgetfulness, such as not checking before crossing a road, or inattentiveness, such as crossing a road regardless of the traffic (Granié et al., 2013). Aggressive behaviors are destructive pedestrian behaviors that jeopardize interactions with other road users (Granié et al., 2013). Positive behaviors include prosocial pedestrian behaviors that improve interactions with other road users (Granié et al., 2013). 
Previous studies have reported a relationship between pedestrian behaviors and safety outcomes. Except for positive behaviors, all other pedestrian behaviors are significantly related to different safety outcomes (Deb et al, 2017; Demir, 2017; Mcllyroy et al, 2019; Y1ldırım, 2007). Previous accident involvement as a pedestrian is associated with violations while accident involvement causing traffic injuries is associated with errors and lapses. In addition, severity of injury is associated with lapses and aggressive behaviors (Deb et al., 2017). Pedestrians with accident involvement or near-miss story have reported lapses more frequently than pedestrians without accident involvement or near-miss story (Demir, 2017). Previous accident involvement as any road user is associated with lapses and aggressive behaviors because there are significant differences in these behaviors between pedestrians with accident involvement (one time or several times) and without accident involvement (McIlroy et al., 2019). Finally, aggressive pedestrian behaviors correlate with pedestrians' near misses (Yıldırım, 2007).

All in all, the present study argues that TSC can be a factor that is related to risky traffic behaviors for both drivers and pedestrians. Traffic signs that guide road users' traffic behaviors increase safety and mobility in traffic. To fulfill this aim, signs must firstly be sufficiently comprehensible by road users (Murat \& Çakı1, 2017). As Dewar (1988) reports, TSC is the most important characteristic. For example, drivers who do not understand the meaning of the "bend to the right" sign may ignore it, causing unsafe driving or a traffic accident. Misunderstanding traffic signs not only reduces their safety benefit but may even cause accidents (Zhang \& Chan, 2013). In short, comprehending traffic signs accurately is the most important prerequisite for an effective traffic sign system.

TSC is affected by both sign-related and road user-related factors. Various studies have examined the effects of traffic sign-related factors (e.g. familiarity, concreteness, complexity, meaningfulness, and semantic proximity) on traffic signs ( $\mathrm{Ng} \&$ Chan, 2007; 2008; Qu \& Liu, 2012). Turning to road user-related factors in sign comprehension, studies have examined various demographic factors, such as age, gender, education and driver experience (Zhang \& Chan, 2013). Although there is some evidence that old age reduces comprehension (Ben-Bassat \& Shinar, 2015), other studies reported no significant effect. $\mathrm{Ng}$ and Chan (2008) found that the length of time holding a driving license negatively predicted TSC, but age, years of active driving, and driving hours did not. Some studies find males understand traffic signs better than females (Al-Madani \& Al-Janahi, 2002) whereas other studies (Ng \& Chan, 2007) report no significant gender effect. In contrast, educational level consistently increases TSC (Al-Madani \& Al-Janahi, 2002; Ng \& Chan, 2008; Zhang \& Chan, 2013).

The most important issue is how correctly road users understand the meaning of traffic signs. According to the International Organization for Standardization (ISO), 67\% is the minimum acceptable accuracy in a comprehension test (as cited in Hou \& Yang, 2020). However, Zhang and Chan (2013) reviewed studies from many countries that indicate that comprehension levels are often lower than this threshold. Regarding Turkey specifically, Murat and Çakıcı (2017) found that Turkish drivers had insufficient comprehension of 10 of 27 traffic signs (about 40\%). Kirmizioglu and Tuydes-Yaman (2012) reported over $69 \%$ of participants correctly understood 12 out of 39 traffic signs. Lastly, Şehribanoğlu (2019) found that $68 \%$ of participants evaluate themselves as having insufficient TSC. In short, TSC, which is one of key factors in risky traffic behaviors, seems be poor in Turkey.

Various studies have examined the relationship between TSC and safety outcomes. Al-Madani (2000) found no relationship between TSC and drivers' accident involvement or speeding citations, although TSC was positively related to seat belt use. Researchers assume there is a relationship between TSC and risky driving and/or pedestrian behaviors, although this is only rarely reflected in accidents. However, no 
study has specifically investigated TSC and risky traffic behaviors, as previous research has focused on signrelated factors and driver demographic characteristics. Hence, the relationship between TSC and human behavior remains unexamined. Regarding developing countries particularly, it also seems plausible that insufficient knowledge or awareness of traffic rules and regulations, including traffic signs, may be related to risky driver behaviors (Chakrabarty et al., 2013; Kirmizioglu \& Tuydes-Yaman, 2012).

The present study, therefore, aimed to fill this gap in the literature by providing a more detailed understanding of the human factor in TSC. We hypothesized that TSC is related to risky traffic behaviors by both drivers and pedestrians. However, we offered no hypothesis about positive pedestrian behaviors as previous studies have not found any associations with safety outcomes.

\section{Method}

\section{Participants}

The data were collected from 275 road users, ranging from 14 to 61 years in age $(M=28.56$ years, $S D=10.27$. Of these, $64.4 \%$ said they drove $(N=177)$ while the others $(N=98)$ considered themselves pedestrians, although some $(N=43)$ had driving licenses. $62.5 \%$ of the participants were females $(N=172)$ and $36.4 \%$ were males $(N=100)$, but three participants did not report their gender $(1.1 \%)$. The demographic characteristics are presented in Table 1.

Table 1

Participants Demographic Characteristics by Road User Type

\begin{tabular}{llll}
\hline Variable & Total & Drivers & Pedestrians \\
\hline$N(\%)$ & $275(\% 100)$ & $177(64.4 \%)$ & $98(35.6 \%)$ \\
Women $(\%)$ & $172(62.5 \%)$ & $98(55.4 \%)$ & $74(75.5 \%)$ \\
Men $(\%)$ & $100(36.4 \%)$ & $77(43.5 \%)$ & $23(23.5 \%)$ \\
Age (years) & & & $14-61$ \\
$\quad$ Min-Max & $14-61$ & $18-56$ & 25.61 \\
$\quad$ Mean & 28.56 & 30.18 & 9.33 \\
SD & 10.27 & 10.42 & $44(44.9 \%)$ \\
Driver License $(\%)$ & $221(80.4 \%)$ & $177(\% 100)$ & $3(3.1 \%)$ \\
Education & & & $2(2 \%)$ \\
$\quad$ Elementary School & $3(1.1 . \%)$ & 0 & $22(22.4 \%)$ \\
$\quad$ Secondary School & $2(.7 \%)$ & 0 & 0 \\
High School & $36(13.1 \%)$ & $14(7.9 \%)$ & $67(68.4 \%)$ \\
Two-year degree & $10(3.6 \%)$ & $10(5.6 \%)$ & $4(4.1 \%)$ \\
Undergraduate & $198(72 \%)$ & $131(74 \%)$ & $22(12.4 \%)$ \\
Graduate & $26(9.5 \%)$ & & \\
\hline
\end{tabular}

Note. Driver group is composed of people who are reported to be actively driving while pedestrians in this table correspond who do not.

\section{Measurements}

Pedestrian Behavior Scale: The Pedestrian Behavior Scale (PBS), originally developed by Granié et al. (2013) and translated into Turkish by Nordfjærn and Şimşekoğlu (2013) is a seven-point Likert-type measure of pedestrian behavior. A 20-item revised form was used, which included additional positive pedestrian behavior items, translated into Turkish by Demir (2017). The scale consists of four factors: transgressions, lapses, aggressive behaviors, and positive behaviors. Cronbach's alpha internal consistency values were $.87, .83, .79$, and .66 , respectively. 
Mini-Driver Behavior Questionnaire: The Mini-Driver Behavior Questionnaire (mini-DBQ), developed by Martinussen et al. (2013) is a self-report measure of driver behavior using a five-point Likert-type scale. It has 9 items assessing lapses, errors, and ordinary violations. For the current study, 3 items were added to measure aggressive violations taken from the original DBQ (Lajunen et al., 1998) and translated into Turkish by Sümer et al. (2002) and Sümer and Özkan (2002). Cronbach's alpha internal consistency values were .58 for lapses, .62 for errors, .75 for ordinary violations, and .82 for aggressive violations.

Traffic Signs: The researchers selected 25 traffic sign images taken from the official webpage of the National General Directorate of Highways (KGM) of Turkey (KGM, 2020). There were 10 hazard warning signs, 12 traffic management signs, one information sign, and 2 stop and parking signs (KGM, 2020). Participants were presented the traffic signs in an online questionnaire battery and asked to write their meaning in an open-ended blank space. Five of the signs were categorized as pedestrian-related whereas all 25 traffic signs were coded as driver-related. Two researchers coded the open-ended answers as follows, in line with Kirmizioglu and Tuydes-Yaman (2012). Opposite incorrect answers were coded as -2, nonopposite incorrect answers were coded as -1 , blank answers or answers stating "I do not know" were coded as 0 , partially correct answers were coded as 1 , and completely correct answers were coded as 2 .

Demographic Information Form: Participants were asked to provide information about age, gender, education level, holding a driver's license, driving experience (Are you driving? $0=$ Yes, $1=$ No), accident involvement (as both driver and pedestrian), traffic sign violations, and near misses for pedestrians.

\section{Procedure}

This research was approved by the Başkent University Social and Humanities and Art Research Board. Informed consent was obtained from each participant. Participants were invited through social media and received the questionnaire battery online using Qualtrics. The data was analyzed with SPSS 20.

\section{Results}

\section{Descriptive Statistics}

Overall comprehension level for drivers was $74.6 \%$, with $56.3 \%$ completely correct and $17.3 \%$ partially correct answers. Overall comprehension level for pedestrians was $76 \%$, with $67.1 \%$ completely correct and $8.9 \%$ partially correct answers. The answers for "no comment" were $7.9 \%$ and $8.9 \%$ for drivers and pedestrians, respectively. Incorrect answers were $13.6 \%$ for drivers, and $14.7 \%$ for pedestrians. Lastly, the opposite answers were $4.4 \%$ for drivers and $2.4 \%$ for pedestrians. The detailed TSC levels of participants for each traffic sign were presented in the appendices. Table 2 presents the correlations between the study variables.

\section{Regression Analyses}

Relationships between TSC and Driver Behaviors: A series of regression analyses were conducted to examine the relationships between TSC and each DBQ dimension (ordinary violations, errors, lapses, and aggressive violations) after controlling for gender and age. As shown in Table 3, the results for ordinary violations indicated that Model 1, which included gender and age was significant, explaining from $14 \%$ of the variance $(F(2,162)=12.62, p<.001)$. Age was negatively related to this dimension $(\beta=-.28, p<.001)$ while male gender was positively related $(\beta=-.33, p<.001)$. However, Model 2 , which included TSC, made no significant contribution to the equation. 
Table 2

Correlations between study variables

\begin{tabular}{|c|c|c|c|c|c|c|c|c|c|c|c|c|c|c|c|c|c|}
\hline & 1 & 2 & 3 & 4 & 5 & 6 & 7 & 8 & 9 & 10 & 11 & 12 & 13 & 14 & 15 & 16 & 17 \\
\hline 1. Gender & - & & & & & & & & & & & & & & & & \\
\hline 2. Age & $-.16^{* *}$ & - & & & & & & & & & & & & & & & \\
\hline 3. TSC & .02 & $.26^{* * *}$ & - & & & & & & & & & & & & & & \\
\hline 4. PTSC & .12 & $.19^{* *}$ & $.77^{* * *}$ & - & & & & & & & & & & & & & \\
\hline 5. Dorv & $-.26^{* *}$ & $-.18^{*}$ & -.09 & -.08 & - & & & & & & & & & & & & \\
\hline 6. Derr & -.02 & $-.21^{* *}$ & $-.27^{* *}$ & $-.22^{* *}$ & $.30^{* * *}$ & - & & & & & & & & & & & \\
\hline 7. Dlap & $.17^{*}$ & $-.18^{*}$ & $-.26^{* *}$ & -.14 & .14 & $.57^{* * * *}$ & - & & & & & & & & & & \\
\hline 8. Dagv & $-.16^{*}$ & $-.23^{* *}$ & $-.19^{*}$ & -.12 & $.70^{* * * *}$ & $.32^{* * *}$ & $.24^{* *}$ & - & & & & & & & & & \\
\hline 9. Ptra & $-.22^{* * *}$ & $-.35^{* * *}$ & $-.23^{* * *}$ & $-.24^{* * *}$ & $.40^{* * *}$ & $.20^{*}$ & .05 & $.35^{* * *}$ & - & & & & & & & & \\
\hline 10. Plap & .04 & $-.19^{* *}$ & $-.28^{* * *}$ & $-.22^{* * * *}$ & $.23^{* *}$ & $.40^{* * *}$ & $.42^{* * *}$ & $.19^{*}$ & $.37^{* * *}$ & - & & & & & & & \\
\hline 11. Pagb & $-.19^{* *}$ & $-.27^{* * *}$ & $-.22^{* * *}$ & $-.20^{* *}$ & $.56^{* * *}$ & $.42^{* * *}$ & $.21^{* *}$ & $.71^{* * * *}$ & $.36^{* * *}$ & $.31^{* * *}$ & - & & & & & & \\
\hline 12. Pposb & $-.20^{* *}$ & $.23^{* * * *}$ & $.23^{* * *}$ & $.21^{* *}$ & .03 & $-.16^{*}$ & -.13 & -.08 & .05 & -.04 & -.03 & - & & & & & \\
\hline 13. Pacci & -.05 & -.10 & -.03 & .01 & .01 & -.06 & .02 & .05 & .07 & .01 & $.12^{*}$ & -.04 & - & & & & \\
\hline 14. Pnemis & -.03 & $-.20^{* *}$ & -.10 & $-.15^{*}$ & .04 & .09 & .06 & .13 & $.36^{* * * *}$ & $.30^{* * *}$ & $.17^{* *}$ & .04 & $.19^{* *}$ & - & & & \\
\hline 15. Daacci & .06 & -.02 & -.01 & -.06 & .15 & .12 & .09 & $.18^{*}$ & .05 & .12 & .11 & -.04 & .03 & .10 & - & & \\
\hline 16. Dpacci & -.03 & -.07 & .01 & .04 & .14 & .04 & .05 & $.25^{* *}$ & .00 & -.05 & $.21^{* *}$ & -.10 & $.41^{* * *}$ & $.20^{* * *}$ & $.27^{* * *}$ & - & \\
\hline 17. Gaci & .03 & -.13 & .00 & .04 & $.19^{*}$ & .12 & .11 & $.29^{* * *}$ & .07 & .02 & $.21^{* *}$ & -.13 & $.24^{* *}$ & .13 & $.54^{* * *}$ & $.71^{* * *}$ & - \\
\hline 18. TSV & .03 & .12 & -.06 & .02 & -.07 & .10 & .03 & .01 & -.05 & -.03 & -.01 & $-.18^{*}$ & -.03 & -.05 & -.06 & -.08 & -.08 \\
\hline
\end{tabular}

Note. ${ }^{*} p<.05 ; * * p<.01 ; * * * p<.001 ;$ TCS = Traffic Sign Comprehension; PTSC = Pedestrian Related Traffic Sign Comprehension; DBQ = Driver Behavior Questionnaire; PBS = Pedestrian Behavior Scale; Dorv = Ordinary violations of DBQ; Derr = Errors of DBQ; Dlap = Lapses of DBQ; Dagv = Aggressive violations of DBQ; Ptra = Transgressions of PBS; Plap = Lapses of PBS; Pagb =Aggressive Behaviors of PBS; Pposb = Positive Behaviors of PBS; Pacci = Pedestrian accident involvement; Pnemiss; Pedestrian near miss; Daacci = Driver active accident involvement; Dpacci = Driver passive accident involvement; Gaci $=$ General accident involvement; TSV = Traffic sign violations.

Regarding errors, the variance in this DV explained by age and gender in Model 1 was significant $\left(R^{2}=.05, F(2,162)=4.01, p<.05\right)$. While gender was unrelated to this dimension, age was negatively related $(\beta=-.23, p<.01)$. Model 2 , which included TSC, added significant incremental variance in explaining errors $\left(\Delta R^{2}=.06, F_{\text {change }}(1,161)=11.12, p<.01\right)$. TSC was negatively related to errors $(\beta=-$ $.25, p<.01)$. For lapses, the variance explained by gender and age in Model 1 was significant $\left(R^{2}=.05\right.$, $F(2,162)=3.81, p<.05)$. However, neither age nor gender was significantly associated with this dimension in this model. Model 2, which included TSC, added significant incremental variance in explaining lapses $\left(\Delta R^{2}=.07, F_{\text {change }}(1,161)=11.81, p<.01\right)$. TSC was negatively related to lapses $(\beta=.-.26, p<.01)$. Finally, for aggressive violations, the variance in this DV explained by gender and age in Model 1 was significant $\left(R^{2}=.11, F(2,162)=9.82, p<.001\right)$. Both age $(\beta=.-.30, p<.001)$ and gender $(\beta=.-.24, p<.01)$ were significantly associated with this dimension. Model 2, which included TSC, did not add significant incremental variance in explaining aggressive violations. 
Table 3

Model Summary of Hierarchical Regression Analyses Examining Relationships between Traffic Sign Comprehension and each DBQ Dimension (ordinary violations, errors, lapses, and aggressive violations) after Controlling for Age and Gender

\begin{tabular}{|c|c|c|c|c|c|c|c|c|c|c|c|c|c|c|c|c|}
\hline & \multicolumn{4}{|c|}{ Ordinary Violations } & \multicolumn{4}{|c|}{ Errors } & \multicolumn{4}{|c|}{ Lapses } & \multicolumn{4}{|c|}{ Aggressive Violations } \\
\hline & $\beta$ & $S E$ & $\Delta R^{2}$ & $F_{\text {change }}$ & $\beta$ & $S E$ & $\Delta R^{2}$ & $F_{\text {change }}$ & $\beta$ & $S E$ & $\Delta R^{2}$ & $F_{\text {change }}$ & $\beta$ & $S E$ & $\Delta R^{2}$ & $F_{\text {change }}$ \\
\hline Step 1 & & & $.14^{\text {**** }}$ & $12.62^{\text {**** }}$ & & & $.05^{*}$ & $4.01^{*}$ & & & $.05^{*}$ & $3.81^{*}$ & & & $.11^{* * * *}$ & $9.82^{* * * *}$ \\
\hline GE & $-.33^{* * *}$ & .16 & & & -.09 & .09 & & & .13 & .11 & & & $-.24^{* *}$ & .15 & & \\
\hline Age & $-.28^{* *}$ & .01 & & & $-.23^{* *}$ & .00 & & & -.14 & .01 & & & $-.30^{* * *}$ & .01 & & \\
\hline Step 2 & & & .00 & .33 & & & $.06^{* *}$ & $11.12^{* *}$ & & & $.07^{* *}$ & $11.81^{* * *}$ & & & .02 & 3.75 \\
\hline TSC & -.04 & .01 & & & $-.25^{* *}$ & .00 & & & $-.26^{* *}$ & .00 & & & -.14 & .01 & & \\
\hline
\end{tabular}

Note . Ge $=$ Gender; TSC $=$ Traffic Sign Comprehension; $N=165 ;{ }^{*} p<.05 ;{ }^{* *} p<.01 ;{ }^{* * *} p<.001$. Gender was coded as $0=$ Male and $1=$ Female Participants who reported to be active drivers are used in the regression analyses.

Relationships between Pedestrian-Related TSC and Pedestrian Behaviors: A series of regression analyses were conducted to examine the relationships between pedestrian-related TSC and each PBS dimension (transgressions, lapses, aggressive behaviors, and positive behaviors) after controlling for gender, age, driving experience, and driving license possession. As can be seen in Table 4, the variance explained by gender and age in Model 1 was significant $\left(R^{2}=.20, F(2,268)=32.45, p<.001\right)$. Age was negatively related to transgressions $(\beta=-.39, p<.001)$ while being male was positively related to this dimension $(\beta=-$ $.28, p<.001)$. Model 2 , which included driving license possession and driving experience, made no significant contribution to the equation. Model 3, which included pedestrian-related TSC, added significant incremental variance in explaining transgressions $\left(\Delta R^{2}=.02, F_{\text {change }}(1,265)=5.18, p<.05\right)$. Pedestrianrelated TSC was negatively related to transgressions $(\beta=-.13, p<.05)$.

Regarding lapses, Model 1, which included gender and age was significant, explaining $4 \%$ of the variance $(F(2,268)=5.20, p<.01)$. While gender was unrelated, age was negatively related to this dimension $(\beta=-.19, p<.01)$. Model 2 , which included driving license and driving, added significant incremental variance in explaining lapses $\left(\Delta R^{2}=.03, F_{\text {change }}(2,266)=4.25, p<.05\right)$. Both variables in Model 2 were unrelated to this dimension. Model 3, which included pedestrian-related TSC, added significant incremental variance in explaining lapses $\left(\Delta R^{2}=.03, F_{\text {change }}(1,265)=7.24, p<.01\right)$. Pedestrianrelated TSC was negatively related to lapses $(\beta=-.17, p<.01)$.

Regarding aggressive behaviors, the variance explained by gender and age in Model 1 was significant $\left(R^{2}=.13, F(2,268)=19.27, p<.001\right)$. Age $(\beta=-.31, p<.01)$ and $\operatorname{gender}(\beta=-.23, p<.01)$ were both negatively related to this dimension. Model 2, which included driving license possession and driving experience, did not make any contribution to the equation. Model 3, which included pedestrianrelated TSC, added significant incremental variance in explaining aggressive behaviors $\left(\Delta R^{2}=.02, F_{\text {change }}(1\right.$, $265)=5.64, p<.05)$. Pedestrian-related TSC was negatively related to aggressive behaviors $(\beta=-.14, p<$ $.05)$.

Finally, the results for positive behaviors indicated that Model 1, which included gender and age, was significant $\left(\Delta R^{2}=.08, F(2,268)=12.35, p<.001\right)$. Age was positively related to this dimension $(\beta=$ $.21, p<.001)$ while being male was negatively related to it $(\beta=-.17, p<.01)$. Model 2 , which included driving license possession and driving experience, did not make any significant contribution to the equation. Model 3, which included pedestrian-related TSC, added significant incremental variance in explaining positive behaviors $\left(\Delta R^{2}=.03, F_{\text {change }}(1,265)=9.46, p<.01\right)$. Pedestrian-related TSC was positively related to positive behaviors $(\beta=.18, p<.01)$. 
Table 4

Model Summary of Hierarchical Regression Analyses Examining Relationships between Pedestrian-Related Traffic Sign Comprehension and each PBS Dimension (Transgressions, Lapses, Aggressive Behaviors, and Positive Behaviors) after Controlling for Gender and Age

\begin{tabular}{|c|c|c|c|c|c|c|c|c|c|c|c|c|c|c|c|c|}
\hline & \multicolumn{4}{|c|}{ Transgressions } & \multicolumn{4}{|c|}{ Lapses } & \multicolumn{4}{|c|}{ Agg. Behavior } & \multicolumn{4}{|c|}{ Pos. Behavior } \\
\hline & $\beta$ & $S E$ & $\Delta R^{2}$ & $F_{\text {change }}$ & $\beta$ & $S E$ & $\Delta R^{2}$ & $F_{\text {change }}$ & $\beta$ & $S E$ & $\Delta R^{2}$ & $F_{\text {change }}$ & $\beta$ & $S E$ & $\Delta R^{2}$ & $F_{\text {change }}$ \\
\hline Step 1 & & & $.20^{* * *}$ & $32.45^{* *}$ & & & $.04^{* *}$ & $5.20^{* *}$ & & & $.13^{* * *}$ & $19.27^{\text {*** }}$ & & & $.08^{* * *}$ & $12.35^{\text {**** }}$ \\
\hline GE & $-.28^{* * * *}$ & .13 & & & .01 & .12 & & & $-.23^{* *}$ & .12 & & & $-.17^{* *}$ & .14 & & \\
\hline Age & $-.39^{* * *}$ & .01 & & & $-.19^{* *}$ & .01 & & & $-.31^{* *}$ & .01 & & & $.21^{* * *}$ & .01 & & \\
\hline Step 2 & & & .01 & .93 & & & $.03^{*}$ & $4.25^{*}$ & & & .01 & 1.69 & & & .02 & 2.19 \\
\hline $\mathrm{DL}$ & -.09 & .22 & & & .15 & .19 & & & -.03 & .19 & & & -.12 & .23 & & \\
\hline Driv. & .09 & .18 & & & .04 & .16 & & & -.09 & .16 & & & -.01 & .19 & & \\
\hline Step 3 & & & $.02^{*}$ & $5.18^{*}$ & & & $.03^{*}$ & $7.24^{* *}$ & & & $.02^{*}$ & $5.64^{*}$ & & & $.03^{* *}$ & $9.46^{* *}$ \\
\hline PTSC & $-.13^{*}$ & .02 & & & $-.17^{* *}$ & .02 & & & $-.14^{*}$ & .02 & & & $.18^{* *}$ & .02 & & \\
\hline
\end{tabular}

Note . Ge = Gender; Driv. = Driving; DL = Driver License; PSC = Pedestrian-related Traffic Sign Comprehension; Agg. Behavior = Aggressive Behaviors; Pos. Behavior = Positive Behavior; $N=271 ;{ }^{*} p<.05 ;{ }^{* *} p<.01 ;{ }^{* * *} p<.001$. Gender was coded as $0=$ Male and $1=$ Female. Driving license possession was coded as $0=$ Yes and $1=$ No. Driving experience was coded as $0=$ Yes and $1=$ No. Total sample are used in the regression analyses since both groups of participants (i.e. active drivers and pedestrians) have pedestrian role in the traffic.

\section{Discussion}

The present study investigated the relationship between TSC and risky traffic behaviors for both drivers and pedestrians. For both driver and pedestrian samples, general TSC can be evaluated as high, since the present finding is higher than the accuracy standard of ISO (as cited in Hou \& Yang, 2020). Still, it should be important to state that high level of education is positively related to TSC (e.g. Ng \& Chan, 2008) and present sample consist of mostly undergraduate level. In addition, it is noteworthy that there is a great diversity in correctly answered traffic signs. As it was presented in appendices, some of the traffic signs were widely understood by participants whereas the others are not. This difference may result from the ease of the meaning of some of the traffic sign such as school zone. In future studies, it can be helpful to include all of the traffic signs to the survey.

In this study, it is hypothesized that TSC is related to risky traffic behaviors by drivers and pedestrians after controlling for demographics. The hierarchical regression analyses for drivers found that both ordinary and aggressive violations were predicted by being young and male. This finding is consistent with the high violation and accident rates for young male drivers reported in the literature (Amarasingha \& Dissanayake, 2014; Laapotti \& Keskinen, 2004). However, contrary to our predictions, neither ordinary nor aggressive violations were related to TSC. Given that violations involve behavioral intention, this finding is not surprising since both kinds of violation result from an intention to violate a rule or engage in an aggressive act (Reason et al., 1990). Hence, for drivers, poor TSC only seems a plausible factor for unintentional risky behaviors.

Additionally, errors were related to old age and poor TSC. On the other hand, analysis for lapses revealed significant negative results for TSC but not the demographic variables. The difference in demographic variables can be explained by the nature of errors and lapses. Errors are actions that fail to achieve the desired end. They are closely related to cognitive functions (Özkan \& Lajunen, 2005; Reason et al., 1990). Thus, a negative relationship between age and errors is predictable. Lapses, on the other hand, are memory failures, so the lack of a relationship between them and age is understandable since memory failures can happen at any age (Erber et al.,1996). As stated above, both errors and lapses were negatively related to 
TSC. Incomprehension or misinterpretation of a traffic sign can lead to several traffic problems, including accidents (Zhang \& Chan, 2013). Thus, poor TSC can easily be linked to driver errors and lapses.

Regarding pedestrian behaviors, transgressions and aggressive behaviors were significantly predicted by being young, male and having low TSC. This is consistent with previous studies, which have shown frequent transgressions and aggressive behaviors in young and male pedestrians (Brosseau, 2013). Consistent with our prediction, which is contrary to that for driver behaviors discussed above, both transgressions and aggressive behaviors, which are both intentional acts, were related to pedestrian-related TSC. This inconsistency between pedestrian and driver behaviors can be explained by the nature of pedestrian behaviors. Specifically, although the origins of both behaviors seem closely related, there are some differences (Granié et al., 2013). In addition, relatively higher sample size in predicting the pedestrian behaviors may explain the differences between pedestrian and driver behaviors in relation to TCS. Lapses are significantly and negatively related to age and TSC. Consistent with our prediction, which is supported by driver behaviors, TSC is significantly related to lapses. Hence, for pedestrians, TSC seems a plausible contributing factor to risky behaviors through both unintentional and intentional processes. Poor TSC can easily be linked to the three different types of risky pedestrian behaviors (transgressions, aggressive behaviors, and lapses), which is in turn related to safety outcomes (Deb et al, 2017; Mcllyroy et al, 2019; Y1ldirım, 2007). Lastly, positive behaviors were related to being old, female, and having better TSC. These demographics differences are consistent with the literature (Granié et al., 2013). In addition, positive interactions between pedestrians and other road users seems to be positively related to TSC. This may be because better TSC increases awareness of other road users, which in turn may increase positive behaviors toward these road users.

The present study has some limitations that need to be considered. First, the present study used selfreport measurements to measure driver behaviors, which may be biased by socially desirable responding. Future studies could use tools such as a driver simulation or other recorded measurement to avoid the biases from self-report measurements. Another limitation concerns the selection of the traffic signs. In the present study, 25 frequently used traffic signs were selected from the KGM web page, based on previous studies' methodology, their frequency in daily traffic, and the length of the survey. Future studies could more comprehensively include all traffic signs. Thirdly, this study included positive pedestrian behavior but not positive driver behavior, which future studies could add (Özkan \& Lajunen, 2005) to see the relationship between this and TSC. Finally, while the regression analyses for driver behaviors used participants who reported that they drive, the regression analyses for pedestrian behaviors used participants who both drive and do not drive. Future studies could investigate the possible differences between pedestrians who reported that they drive or that they have driving licence and pedestrians who reported that they do not drive or that they do not have driving licence.

This study makes several strong contributions to the literature. First, to the best of our knowledge, it is the first to investigate the behavioral component of the human factor in TSC. Although previous studies have provided detailed empirical findings regarding sign-related factors and demographic variables, none have investigated behavioral components. Second, our study focused on the predictive role of TSC. Specifically, previous studies have identified various determining factors of TSC. However, the present study focused on the next step: How does TSC determine aberrant (and positive for pedestrian) behaviors? The present study is also the first to investigate pedestrian behaviors as well as driver behaviors. Lastly, this study provided a detailed investigation of TSC by using a stronger methodology than multiple-choice measurements. Participants' open-ended responses were coded into five categories (completely correct, 
partially correct, no comment, incorrect, and oppositely incorrect). In addition to the aforementioned contributions, the present study suggests some practical implications. TSC training can improve road safety in terms of both driver and pedestrian behaviors. Based on that, a recommendation that focuses on sign comprehension in different levels of education (for pedestrian safety) and driver's education can actually help to reduce aberrant behaviors. In detail, such knowledge-transfer can be very cost-effective for different levels of education. TSC can be taught to both children and adults via games, it can be conducted online, and it can be implemented current safety and driving education system easily.

\section{References}

Al-Madani, H. (2000). Influence of drivers' comprehension of posted signs on their safety related characteristics. Accident Analysis and Prevention, 32(4), 575-581. https://doi.org/10.1016/S00014575(99)00084-6.

Al-Madani H., \& Al-Janahi A.R. (2002). Role of drivers' personel characteristics in understanding traffic sign symbols. Accident Analysis and Prevention, 34, 185-196. https://doi.org/10.1016/S00014575(01)00012-4.

Amarasingha, N., \& Dissanayake, S. (2014). Gender differences of young drivers on injury severity outcome of highway crashes. Journal of Safety Research, 49, 113-120. http:/doi.org/10.1016/j.jsr.2014.03.004.

Ben-Bassat T., \& Shinar D. (2015). The effect of context and drivers' age on highway traffic signs comprehension. Transportation Research Part F: Traffic Psychology and Behaviour, 33, 117-127. https://doi.org/10.1016/j.trf.2015.07.009.

Brosseau, M., Zangenehpour, S., Saunier, N., \& Miranda-Moreno, L. (2013). The impact of waiting time and other factors on dangerous pedestrian crossings and violations at signalized intersections: A case study in Montreal. Transportation Research Part F: Traffic Psychology and Behaviour, 21, 159-172. http:/doi.org/10.1016/j.trf.2013.09.010.

Chakrabarty, N., Gupta, K., \& Bhatnagar, A. (2013). A survey on awareness of traffic safety among drivers in Delhi, India. The SIJ Transactions on Industrial, Financial \& Business Management (IFBM), l(2), 106-109.

Deb, S., Strawderman, L., DuBien, J., Smith, B., Carruth, D.W., \& Garrison, T.M. (2017). Evaluating pedestrian behavior at crosswalks: Validation of a pedestrian behavior questionnaire for the US population. Accident Analysis and Prevention, 106, 191-201. https://doi.org/10.1016/j.aap.2017.05.020.

Demir, B. (2017). The social psychological predictors of pedestrian behaviors [Unpublished doctoral dissertation]. Middle East Technical University

Dewar, R. (1988). Criteria for the design and evaluation of traffic sign symbols. Transportation Research Record, 1160(1), 1-6.

Erber, J. T., Prager, I. G., Williams, M., \& Caiola, M. A. (1996). Age and forgetfulness: Confidence in ability and attribution for memory failures. Psychology and Aging, 11(2), 310-315. https://doi.org/10.1037/0882-7974.11.2.310.

Granié, M. A., Pannetier, M., \& Gueho, L. (2013). Developing a self-reporting method to measure pedestrian behaviors at all ages. Accident Analysis and Prevention, 50, 830-839. https://doi.org/10.1016/j.aap.2012.07.009.

Hou, G., \& Yang, J. (2020). Measuring and examining traffic sign comprehension with event-related potentials. Cognition Technology \& Work. https://doi.org/10.1007/s10111-020-00632-1. 
Kirmizioglu E. \& Tuydes-Yaman H. (2012). Comprehensibility of traffic signs among urban drivers in Turkey. Accident Analysis and Prevention, 45, 135-141. https://doi.org/10.1016/j.aap.2011.11.014.

Laapotti, S., \& Keskinen, E. (2004). Has the difference in accident patterns between male and female drivers changed between 1984 and 2000?. Accident Analysis and Prevention, 36(4), 577-584. https://doi.org/10.1016/S0001-4575(03)00064-2.

Lajunen, T., Parker, D., \& Stradling, S. G. (1998). Dimensions of driver anger, aggressive and highway code violations and their mediation by safety orientation in UK drivers. Transportation Research Part F: Traffic Psychology and Behaviour, 1(2), 107-121. https://doi.org/10.1016/S1369-8478(98)00009-6.

Lajunen, T., Parker, D., \& Summala, H. (2004). The Manchester driver behaviour questionnaire: a crosscultural study. Accident Analysis and Prevention, 36(2), 231-238. https://doi.org/10.1016/S00014575(02)00152-5.

Lawton, R., Parker, D., Manstead, A. S. R., \& Stradling, S. (1997). The role of affect in predicting social behaviours: the case of road traffic violations. Journal of Applied Social Psychology, 27, 1258-1276. https://doi.org/10.1111/j.1559-1816.1997.tb01805.x.

Lewin, I. (1982). Driver training: a perceptual-motor skill approach. Ergonomics, 25(10), 917- 924. https://doi.org/10.1080/00140138208925051.

Mako, E., \& Szakonyi, P. (2016). Evaluation of human behaviour at pedestrian crossings. Transportation Research Procedia, 14, 2121-2128. https://doi.org/10.1016/j.trpro.2016.05.227.

Martinussen, L. M., Hakamies-Blomqvist, L., Møller, M., Özkan, T., \& Lajunen, T. (2013). Age, gender, mileage and the DBQ: The validity of the Driver Behavior Questionnaire in different driver groups. Accident Analysis and Prevention, 52, 228-236. https://doi.org/10.1016/j.aap.2012.12.036.

Martinussen, L. M., Lajunen, T., Møller, M., \& Özkan, T. (2013). Short and user-friendly: The development and validation of the Mini-DBQ. Accident Analysis and Prevention, 50, 1259-1265. https://doi.org/10.1016/j.aap.2012.09.030.

McIlroy, R.C., Plant, K.L., Jikyong, U., Nam, V.H., Bunyasi, B., Kokwaro, G.O., Wu, J., Hoque M. S., Preston, J. M., \& Stanton, N. A (2019). Vulnerable road users in low-, middle-, and high-income countries: Validation of a Pedestrian Behaviour Questionnaire. Accident Analysis and Prevention, 131, 80-94. https://doi.org/10.1016/j.aap.2019.05.027.

Mohamed, D., \& Lotfi, B. (2016). Dimensions of aberrant driving behaviours in Tunisia: identifying the relation between Driver Behaviour Questionnaire results and accident data. International Journal of $\begin{array}{lllll}\text { Injury Control and } & \text { Safety }\end{array}$ https://doi.org/10.1080/17457300.2015.1061559.

Murat, Y. Ş., \& Çakıcı, Z. (2017). Trafik işaretlerinin bilinirliği üzerine bir araştırma: Denizli örneği. Bitlis Eren Üniversitesi Fen Bilimleri Dergisi, 6(1), 21-30. https://doi.org/10.17798/bitlisfen.305485.

National General Directorate of Highways (KGM) (2020). Traffic Signs. https://www.kgm.gov.tr/Sayfalar/KGM/SiteTr/Trafik/TehlikeUyariIsaretleri.aspx.

Ng A.W.Y., \& Chan A.H.S. (2007). The guessability of traffic signs: Effects of prospective-user factors and sign design features. Accident Analysis and Prevention, 39, 1245-1257. https://doi.org/10.1016/j.aap.2007.03.018.

$\mathrm{Ng}$ A.W.Y., \& Chan A.H.S. (2008). The effects of driver factors and sign design features on the comprehensibility of traffic Signs. Journal of Safety Research, 39,321-328. https://doi.org/10.1016/j.jsr.2008.02.031.

Nordfjærn, T., \& Şimşekoğlu, Ö. (2013). The role of cultural factors and attitudes for pedestrian behaviour in an urban Turkish sample. Transportation Research Part F: Traffic Psychology and Behaviour, 21, 181-193. https://doi.org/10.1016/j.trf.2013.09.015. 
Özkan, T., \& Lajunen, T. (2005). A new addition to DBQ: Positive driver behaviours scale. Transportation Research Part F: Traffic Psychology and Behaviour, 8(4-5), 355-368. https://doi.org/10.1016/j.trf.2005.04.018.

Özkan, T., \& Lajunen, T. (2011). Person and environment: Traffic culture. In B. Porter (Ed.), Handbook of Traffic Psychology (pp. 179-192). Academic Press. https://doi.org/10.1016/B978-0-12-3819840.10014-1

Özkan, T., Lajunen, T., Chliaoutakis, J. E., Parker, D., \& Summala, H. (2006). Cross-cultural differences in driving behaviours: A comparison of six countries. Transportation Research Part F: Traffic Psychology and Behaviour, 9(3), 227-242. https://doi.org/10.1016/j.trf.2006.01.002.

Qu, Y. K., \& Liu, Y. C. (2012). Effects of sign design features and training on comprehension of traffic signs in Taiwanese and Vietnamese user groups. International Journal of Industrial Ergonomics, 42(1), 1-7. https://doi.org/10.1016/j.ergon.2011.08.009.

Reason, J., Manstead, A., Stradling, S., Baxter, J., \& Campbell, K. (1990). Errors and violations on the roads: a real distinction?. Ergonomics, 33(10-11), 1315-1332. https://doi.org/10.1080/00140139008925335.

Sümer, N., \& Özkan, T. (2002). The role of driver behavior, skills, and personality traits in traffic accidents. Turkish Journal of Psychology, 17(50), 1-22.

Sümer, N., Lajunen, T., \& Özkan, T. (2002, May 8-12). Sürücü davranışlarının kaza riskindeki rolü: İhlaller ve hatalar [Paper presentation]. Uluslararası Trafik ve Yol Güvenliği Kongresi. Gazi University, Turkey

Şehribanoğlu, S. (2019). Van ilinde yaşayanların trafik işaretleri bilgisi ve trafik kurallarına bakış açıları üzerine bir araştırma. Trafik ve Ulaşım Araştırmaları Dergisi, 2(1), 1-15. https://doi.org/10.38002/tuad.479023.

$\begin{array}{lllll}\text { Turkish Statistical } & \text { Institute (2020). Transportation } & \text { Statistics, } & 2020 .\end{array}$ https://data.tuik.gov.tr/Bulten/Index?p=Karayolu-Trafik-Kaza-Istatistikleri-2020-37436.

World Health Organization (2018). Global Status Report on Road Safety 2018. https://apps.who.int/iris/bitstream/handle/10665/276462/9789241565684 -eng.pdf?ua=1.

Y1ldırım, Z. (2007). Religiousness Conservatism and Their Relationship with Traffic Behavior [Unpublished Master's Thesis]. Middle East Technical University.

Zhang, T., \& Chan, A. H. S. (2013). Traffic sign comprehension: A review of influential factors and future directions for research. In S. I. Ao, O. Castillo, C. Douglas, D. D. Feng, \& J. Lee (Eds.), Proceedings of the International MultiConference of Engineers and Computer Scientists (Vol. II, pp. 1026-1030). International MultiConference of Engineers and Computer Scientists, Hong Kong, China

Zhuang, X., \& Wu, C. (2011). Pedestrians' crossing behaviors and safety at unmarked roadway in China. Accident Analysis and Prevention, 43(6), 1927-1936. https://doi.org/10.1016/j.aap.2011.05.005. 


\section{Appendices}

Table 1

Percentages of Traffic Sign Comprehension

Traffic Sign

Drivers $(N=177)$

Pedestrians $(N=98)$
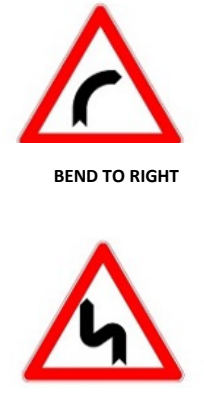

DOUBLE CURVE FIRST TO LEFT

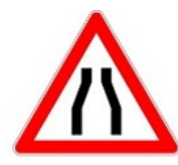

ROAD NARROWS ON BOTH SIDES

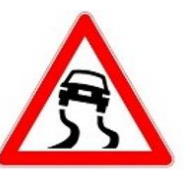

SLIPPERY ROAD

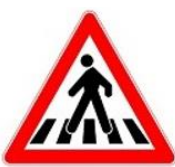

PEDESTRIAN CROSSING AHEAD

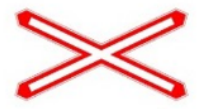

27.7

44.6

$$
9
$$

16.9

1.7

15.3

22.4

16.3

45.9

SINGLE-TRACK LEVEL CROSSING WITHOUT GATES

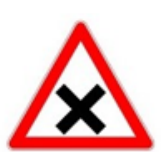

UNCONTROLLED CROSSROAD AHEAD 


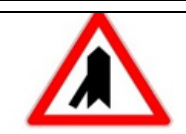

TRAFFIC MERGING FROM LEFT AHEAD

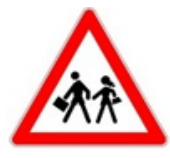

SCHOOL CROSSING
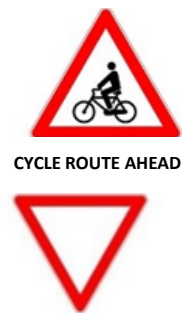

GIVE WAY

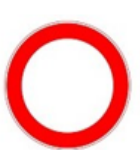

CLOSED TO ALL VEHICLES IN BOTH DIRECTIONS

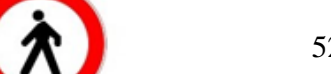

NO ENTRY FOR PEDESTRIANS

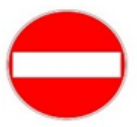

NO ENTRY

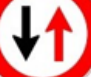

PRIORITY FOR ONCOMING TRAFFIC

$$
\infty
$$

NO ENTRY FOR BICYCLES

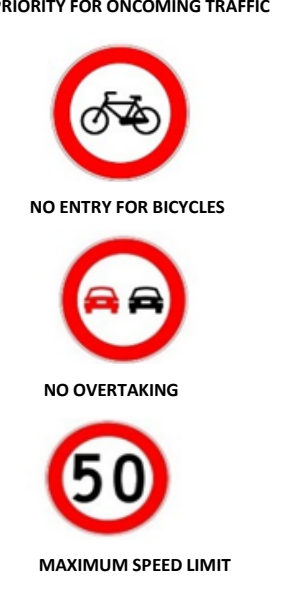

NO OVERTAKING

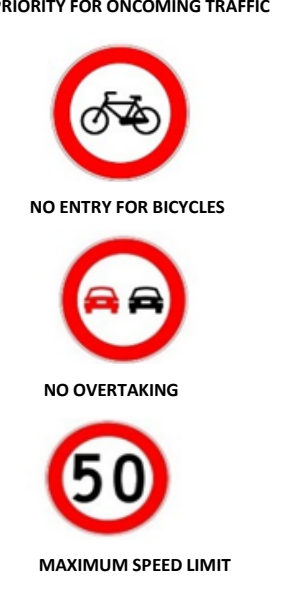

MAXIMUM SPEED LIMIT

53.7

52.5

69.5

78

59.3

25.4

6.2

6.2

2.8

50

18.4

13.3

10.2

8.2

93.2

6.2

.6

0

0

85.7

10.2

2

0

2

$\begin{array}{llllllllll}42.4 & 53.1 & 1.1 & 0 & 3.4 & 45.9 & 51 & 0 & 0 & 3.1\end{array}$

55.4

1.7

14.7

27.7

6

34.7

1

$39.8 \quad 24.5$

0

2.8

26

17.5

32.7

1

38.8

22.4

5.1

52

0

7.9

36.7

3.4

36.7

0

12.2

42.9

8.2

67.2

9

2.3

21.5

0

64.3

8.2

6.1

21.4

0

34.5

$$
.6
$$

5.1

59.3

.6

22.4

5.1

10.2

62.2

0

21.5

6.2

5.1

36.2

38.8

0

$4.1 \quad 16.3$

40.8

$\begin{array}{lll}69.5 & 1.1 & 3.4 \\ & \end{array}$

$21.5 \quad 0$

0

.6

$\begin{array}{lllll}71.4 & 28.6 & 0 & 0 & 0\end{array}$




\section{0}

MINIMUM SPEED LIMIT

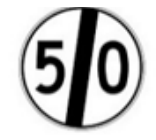

END OF SPEED LIMIT

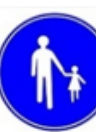

MANDATORY PATH FOR PEDESTRIANS

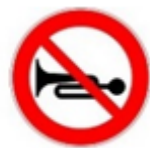

NO HONKING

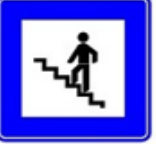

PEDESTRIAN OVERPASS

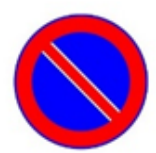

PARKING PROHIBITED

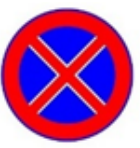

NO STANDING OR PARKING
49.7

6.8

10.2

14.3

11.2

3.1

39.8

52.2

0

25.4

10.7

11.9

32.7

0

42.9

10.2

14.3

63.8

1.7

20.9

13

6

45.9

1

22.4

30.6

0

91

6.8

2.3

0

0

78.6

9.2

9.2

3.1

0

62.1

25.4

6.8

3.4

2.3

68.4

22.4

8.2

o

1

54.8

5.1

11.3

26.6

2.3

43.9

2

25.5

28.6

0

40.7

34.5

11.3

13.6

\begin{abstract}
0
\end{abstract}
29.6

23.5

21.4

24.5

1

TOTAL \%

17.3

7.9

14.2

4.4

67.1

6.7

8.9

14.7

2.4

Note. Most of translations based on Kirmizioglu (2010). Total scores for pedestrians were aggregated from the five pedestrian related signs (marked in bold). Other percentages for pedestrians are presented for descriptive purposes only. This table showed the percentages of traffic sign compherension for both drivers and pedestrians who reported that they do not drive separately. 